\title{
Host taxonomic relatedness and functional-group affiliation as predictors of seaweed-invertebrate epifaunal associations
}

\author{
Colin R. Bates* \\ Bamfield Marine Sciences Centre, 100 Pachena Road, Bamfield, British Columbia V0R 1B0, Canada** \\ and Department of Botany, University of British Columbia, Room 3529, 6270 University Boulevard, Vancouver, \\ British Columbia V6T 1Z4, Canada
}

\begin{abstract}
To test the efficacy of seaweed taxonomic relatedness and morphological/functionalgroup membership as predictors of host-use by invertebrate epifauna, I sampled invertebrate assemblages associated with 1652 individual thalli across 32 species of seaweed. Additionally, I tested whether seaweeds within the same functional group had the potential, in the context of species loss, to functionally replace each other as habitat. In total, I found 54776 individuals across 98 taxa of invertebrates. Similarity of invertebrate assemblages did not decrease as taxonomic distances between seaweed hosts increased; invertebrate assemblages were as different on sibling algal species as on hosts classified in different kingdoms. The utility of seaweeds as hosts for mobile invertebrates varied across components of invertebrate diversity. Invertebrate assemblage composition was different across most algal functional groups, whereas invertebrate taxon richness was different for ca. $25 \%$ of functional groups, and no differences in invertebrate abundance across algal functional groups were observed. There was substantial variation in host-use within seaweed functional groups, suggesting that overall functional group performance indicates little about the performance of the constituent species. Specifically, composition, richness and abundance of invertebrate assemblages were different across most hosts within each algal functional group. Therefore, in the event of seaweed species loss, replacements by members of the same functional group generally appear unlikely. These observations bring into question the use of general frameworks for predicting performance of seaweeds as hosts for associated invertebrates; it appears that invertebrate selection of seaweed hosts is largely dependent upon the identity of the host species.
\end{abstract}

KEY WORDS: Seaweed $\cdot$ Invertebrate $\cdot$ Habitat $\cdot$ Taxonomic relatedness $\cdot$ Functional groups

\section{INTRODUCTION}

For small mobile invertebrates, seaweeds are a refuge from stressful conditions associated with life on rocky intertidal shores. Seaweeds provide cool, wet, and protective canopies and interstices (Hayward 1980,1988 ) and can ameliorate the influence of rapid changes in temperature, ultraviolet radiation, desiccation, and hydrodynamic forces caused by twice-daily emersion and immersion by seawater. At high tides, seaweeds can also offer shelter from predation by fish (Holmlund et al. 1990, Martin-Smith 1993, Norderhaug et al. 2005). Myriad invertebrate taxa use seaweeds as habitat (Colman 1939) and, in some cases, as a food source (Hawkins \& Hartnoll 1983, Arrontes 1999). Epifauna composition, taxon richness, and abundance often differ across species of host seaweed (Colman 1939, Seed \& O'Connor 1981, Taylor \& Cole 1994). In the present study, I explore several general frameworks that hold promise for predicting such patterns of invertebrate biodiversity based on seaweed traits.

Behavioral choices by epifauna determine invertebrate distributions across seaweeds, each seeking and remaining upon their preferred host (Hayward 1988). 
Criteria for epifauna host choice include factors internal to seaweeds: material properties such as cell structure and cell wall components, energetic storage products, and defensive biochemistry (Hay et al. 1987, Graham \& Wilcox 2000, Padilla \& Allen 2000, Van Alstyne \& Houser 2003). These properties vary across seaweeds, resulting in differences in nutritive value and palatability (Paine \& Vadas 1969, Hawkins \& Hartnoll 1983). In addition to negatively acting to directly deter epifauna (Hay et al. 1987), algal defensive biochemistry can act positively to promote epifauna by conferring associational defenses: e.g. unpalatable algae are avoided by omnivorous fishes, and epifauna therefore escape predation (Hay et al. 1990). Along with these internal seaweed features, epifauna also select seaweed hosts based on external features. Architectural complexity of overall seaweed form has widely been linked to abundance and richness of invertebrates (Dean \& Connell 1987, Gee \& Warwick 1994, Taylor \& Cole 1994, Davenport et al. 1996, Hull 1997, Chemello \& Milazzo 2002). Compared to simple forms such as unbranched blades and crusts, complex, highly branching seaweeds can better provide predator-free space for epifauna (Duffy \& Hay 1991), stay moist to limit desiccation effects (Ji \& Tanaka 2002), and provide increased surface area and microhabitat variety (Christie et al. 2003, Norderhaug et al. 2005).

At present, scientific perception about the quality of different seaweeds as hosts for small mobile epifauna are based on a body of studies that compare performance of relatively few seaweed species, typically between 2 (Kraufvelin \& Salovius 2004, Wikström \& Kautsky 2004) and 7 (Holmlund et al. 1990), but sometimes up to 10 (Taylor \& Cole 1994, Taylor \& Steinberg 2005). However, a key goal of community ecology is to establish general principles that describe how biotic and abiotic factors structure biological assemblages (MacArthur 1972). To alleviate the need to compare the performance of particular algal species as hosts for epifauna, a more general predictive framework is desirable. The objective of the present study is to compare 2 such general frameworks: seaweed taxonomic relatedness and seaweed functional form groupings.

Ecologists are increasingly recognizing that taxonomic relationships between species can inform predictions about species performance in an ecological context (Webb et al. 2002). Species that are closely related are more likely to share traits (i.e. similarity by common descent) and thus perform similarly in ecological scenarios. Taxonomic relatedness may inform predictions of seaweed-host performance because internal features of seaweeds (material properties, nutritive value, and defensive chemistry) tend to be conserved within taxonomic lineages. However, a property that could confound the use of seaweed taxonomic related- ness as a predictor of associated epifauna is external morphology, which in seaweeds can vary seemingly independently of taxonomic affinity. Indeed, some genera such as Codium and Caulerpa contain a wide array of morphologies (Silva 1992), while convergent evolution has resulted in strikingly similar forms shared by algae classified as distantly as subkingdom (e.g. Ulva lactuca, a green alga from Subkingdom Viridiplantae and Porphyra spp., red algae from the Subkingdom Biliphyta) and kingdom (e.g. Analipus japonicus, a brown alga [Kingdom Chromista] and Cumagloia andersonii, a red alga [Kingdom Plantae]). This similarity in morphology across taxonomic groupings has been formally recognized since the early 1980s and led to the proposal of morphologically based 'functional form' groupings under which predictions of ecological and ecophysiological performance of seaweeds could be made (Littler \& Littler 1980, Steneck \& Watling 1982, Steneck \& Dethier 1994). The use of terrestrial plant functional groups has also become common in recent times (Lavorel et al. 1997, Diaz \& Cabido 2001). In a review of the performance of algal functional groups, Padilla \& Allen (2000) were critical of previous applications of seaweed functional form models, highlighting a lack of empirical support for most of the model predictions despite widespread acceptance of their use. They did, however, make a point of suggesting the promise of functional form groupings for predicting structure of habitat for associated organisms. This idea remains untested, although see Hacker \& Steneck (1990) who discussed several habitat-providing algal species based on their functional group placement.

Inherent in the concept of using functional groupings to predict ecological or ecophysiological properties is the idea that species grouped together will perform similarly. This premise has been discussed in terms of functional redundancy (Naeem 1998, Fonseca \& Ganade 2001, Rosenfeld 2002, Loreau 2004). This concept is relevant to discussions about the consequences of changes in biodiversity because loss of particular species could be compensated for by functionally equivalent coexisting species. This buffering capacity of species rich assemblages has been viewed as a form of biological insurance (Thebault \& Loreau 2006); however, to date, direct tests of the functional equivalence of seaweeds as hosts for invertebrates are limited to comparisons of only 2 seaweed taxa, e.g. Cladophora glomerata and Fucus vesiculosus (Kraufvelin \& Salovius 2004).

To test the efficacy of seaweed taxonomic relatedness and functional group affinity as predictors of seaweed-invertebrate epifauna associations, I asked 3 questions: (1) is similarity of invertebrate assemblages positively correlated with algal host taxonomic relat- 
edness; (2) does invertebrate assemblage structure differ across seaweed functional groups; and (3) is the performance of seaweed species as habitat for small mobile invertebrates similar within algal functional groups?

\section{MATERIALS AND METHODS}

Study sites. Collections of host algae and associated invertebrates were taken at 6 rocky intertidal sites along southern Barkley Sound, British Columbia, Canada (Fig. 1). Each site was sampled once per month over 11 mo (March 2005 to January 2006) during spring tides.

Sample collections. At each sampling event (site per date), representatives of 3 to 7 algal species were haphazardly collected along a horizontal belt transect that measured $1 \times 30 \mathrm{~m}$, centred at $1 \mathrm{~m}$ above chart datum. To minimize the variation due to vertical shifts in abiotic and biotic structuring factors, species typical of the upper intertidal zone (e.g. Fucus) were collected from the bottom of their vertical range, and lower species (e.g. Mazzaella and Chondracanthus) were collected at the upper reaches of their distribution. I sampled 8 individual thalli per algal species, and each thallus was

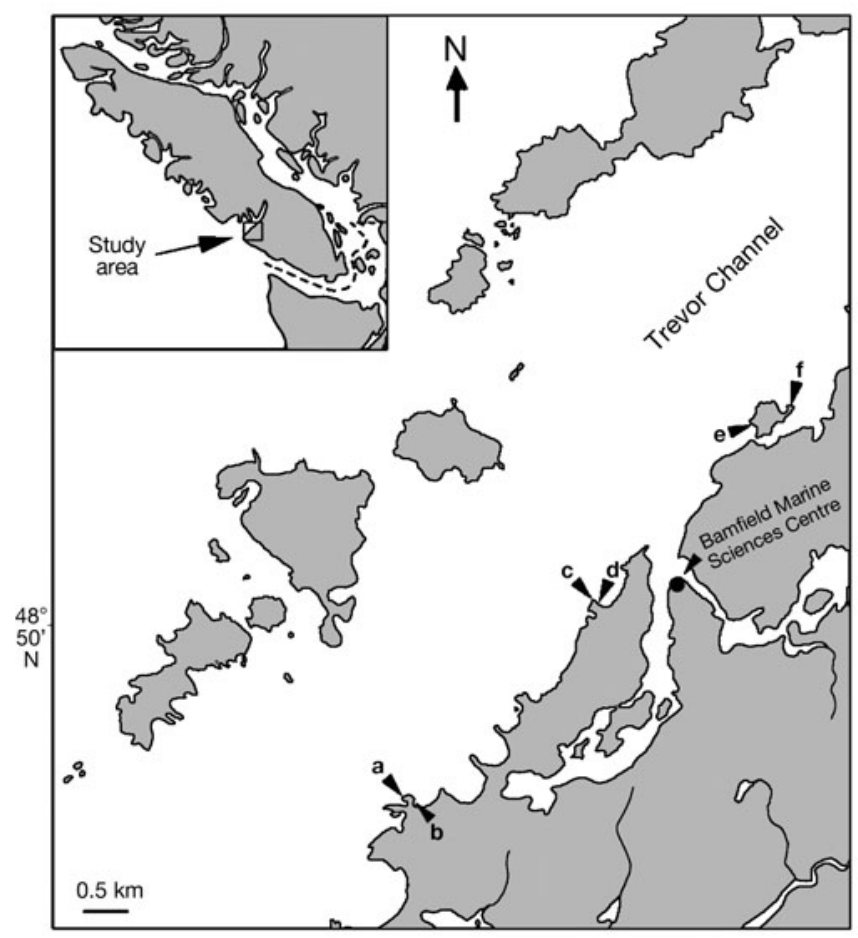

Fig. 1. Study area in southern Barkley Sound, indicating 6 study sites: Nudibranch Point (a: exposed; b: sheltered), Scott's Bay (c: exposed; d: sheltered), and Dixon Island (e: exposed; f: sheltered). Inset shows Vancouver Island, British Columbia, Canada sealed in a zippered collection bag. Algal species were selected if they were abundant at the site, and also to maximize taxonomic and functional representation within the overall data set. In total, 1652 algal thalli were collected across 32 algal species (Table 1). Samples were frozen to euthanize epifauna before processing. To remove the epifauna from the host alga, each frozen seaweed thallus was removed from its bag and thawed in a dish with ca. $500 \mathrm{ml}$ of seawater. Most epifauna sank to the bottom of the dish, but each sample was also rubbed and visually inspected to remove remaining epifauna. Thalli with dense branching or folding were processed with additional attention. This approach was highly effective and visual inspection with a dissecting microscope revealed few, if any, epifauna remaining on the thalli. Because sessile invertebrate individuals were relatively scarce (typically bryozoans or barnacles) and difficult to quantify in terms of number of individuals (in the case of the colonial bryozoans), analyses are limited to mobile epifauna. Samples were sieved through a $0.2 \mathrm{~mm}$ screen to retain epifauna and then preserved in a $1.5 \mathrm{ml}$ Eppendorf tube containing $95 \%$ ethanol. Invertebrates were then enumerated as morphospecies and later keyed to the highest taxonomic resolution possible. Host thalli were dried at $80^{\circ} \mathrm{C}$ for $24 \mathrm{~h}$ and then weighed to the nearest $0.01 \mathrm{~g}$ to account for host biomass.

Algal taxonomy and taxonomic distance. Taxonomic affiliations of the 32 included species of host algae (Table 1) were obtained from Gabrielson et al. (2006). Taxonomic ranks ranged from specific epithets to Kingdom. Taxonomic distance between seaweed hosts was calculated by counting the number of steps through a dendrogram of the Linnaean taxonomic hierarchy (Fig. 2).

Algal functional groups. Although several seaweed functional group classifications exist (Littler \& Littler 1980, Steneck \& Watling 1982, Steneck \& Dethier 1994), the groupings are very similar. I chose to use the algal functional groups erected by Steneck \& Dethier (1994) because they included 8 groups compared to the other 2 models, which used 6. Based on similarity in gross morphology, Steneck \& Dethier (1994) grouped algae into microalgae, filamentous, foliose, corticated foliose, corticated terete, leathery, geniculate calcareous, and crustose. I used 7 of these groups (microalgae are not considered), and functional group affiliation of each species is listed in Table 1.

Taxonomic distance analyses. All invertebrate abundances were 4 th-root transformed before multivariate analyses to downweight the contribution of highly abundant invertebrate species to measures of sample similarity (Clarke 1993). Pairwise comparisons of invertebrate assemblage similarity between algal thalli were calculated using the Bray-Curtis similarity mea- 
Table 1. Seaweed species tested as hosts for invertebrate epifauna, with functional group affiliations and number of collected thalli. Taxonomic authorities are available from Gabrielson et al. (2006)

\begin{tabular}{|c|c|c|c|}
\hline Algal host & Functional group & $\mathrm{N}$ & Similarity of invertebrate assemblages ( $\%$ \\
\hline Acrosiphonia arcta & Filamentous & 8 & 44.96 \\
\hline Acrosiphonia coalita & Filamentous & 8 & 56.69 \\
\hline Alaria marginata & Leathery & 54 & 8.62 \\
\hline Analipus japonicus & Corticated & 36 & 40.57 \\
\hline Ceramium pacificum & Filamentous & 42 & 47.57 \\
\hline Chondracanthus exasperatus & Corticated foliose & 107 & 24.85 \\
\hline Cladophora columbiana & Filamentous & 8 & 56.19 \\
\hline Codium fragile & Corticated & 46 & 30.93 \\
\hline Corallina officinalis var. chilensis & Coralline & 8 & 28.73 \\
\hline Corallina vancouveriensis & Coralline & 16 & 41.06 \\
\hline Coralline crust & Crustose & 8 & - \\
\hline Costaria costata & Leathery & 8 & 33.57 \\
\hline Cryptosiphonia woodii & Corticated & 39 & 36.61 \\
\hline Desmarestia ligulata & Corticated & 8 & 11.20 \\
\hline Endocladia muricata & Corticated & 62 & 35.24 \\
\hline Fucus distichus subsp. evanescens & Leathery & 396 & 28.98 \\
\hline Gastroclonium subarticulatum & Corticated & 74 & 43.53 \\
\hline Halosaccion glandiforme & Corticated foliose & 8 & 47.69 \\
\hline Leathesia difformis & Corticated foliose & 8 & 52.25 \\
\hline Mastocarpus papillatus & Corticated foliose/Crustose & $8 / 39$ & $47.64 / 0.90$ \\
\hline Mazzaella splendens & Corticated foliose & 84 & 13.85 \\
\hline Nemalion elminthoides & Corticated & 8 & 27.73 \\
\hline Neorhodomela larix & Corticated & 35 & 49.85 \\
\hline Polysiphonia hendryi & Filamentous & 35 & 36.79 \\
\hline Polysiphonia paniculata & Filamentous & 15 & 27.32 \\
\hline Polysiphonia senticulosa & Filamentous & 7 & 41.51 \\
\hline Porphyra abbottiae & Foliose & 64 & 30.64 \\
\hline Prionitis lyallii & Corticated & 80 & 27.56 \\
\hline Rhizoclonium riparium & Filamentous & 8 & 40.79 \\
\hline Sargassum muticum & Corticated & 46 & 38.56 \\
\hline Ulva lactuca & Foliose & 270 & 30.94 \\
\hline Ulva intestinalis & Foliose & 8 & 37.82 \\
\hline
\end{tabular}

sure (Bray \& Curtis 1957). Analysis of similarities (ANOSIM; Clarke 1993) was used to assess the degree of invertebrate assemblage similarity between host species. The ANOSIM test statistic $(R)$ ranges between -1 and 1 , with values close to zero indicating no difference between sample groups, values closer to 1 a greater difference between groups than within groups, and values closer to -1 greater difference within groups than between groups. The resultant $R$-values were then plotted against taxonomic distance of the 2 hosts being compared. The $R$-values were not normally distributed but exhibited homogeneous variances (Bartlett's test, $F=0.47 \mathrm{p}=0.86$ ), so the nonparametric Wilcoxon signed-ranks procedure was used to test for differences in invertebrate assemblage similarity among taxonomic levels.

Functional group analyses. Across algal functional groups, I used ANOSIM to test for differences in composition of invertebrate assemblages and ANOVA to test for differences in invertebrate abundances and taxon richness. To control for richness differences caused by differences in invertebrate abundance, I rarefied species richness to 20 individuals (Magurran 1988). I used the mean of each algal species as a replicate within each functional group, and, because values of invertebrate abundance and rarefied richness violated assumptions of normality and homogeneity of variance, I used Monte Carlo randomization procedures (Manly 1991) to determine the level of significance of differences across functional groups. Specifically, identity of algal species was shuffled across functional groups, and the original F-statistic was compared to a null distribution of F-statistics created through 4999 of these randomized permutations.

Within functional groups, I used ANOSIM to test across algal species for differences in invertebrate assemblages. To test for differences in values of invertebrate abundance and rarefied richness, Monte Carlo randomization procedures (Manly 1991) were again used to test for between-species differences. Specifically I tested if, for each species comparison, mean $_{\text {species } X}-$ mean $_{\text {species } Y}$ - where $X$ and $Y$ represent all pairwise combinations of species within functional groups-differed significantly from a null distribution 


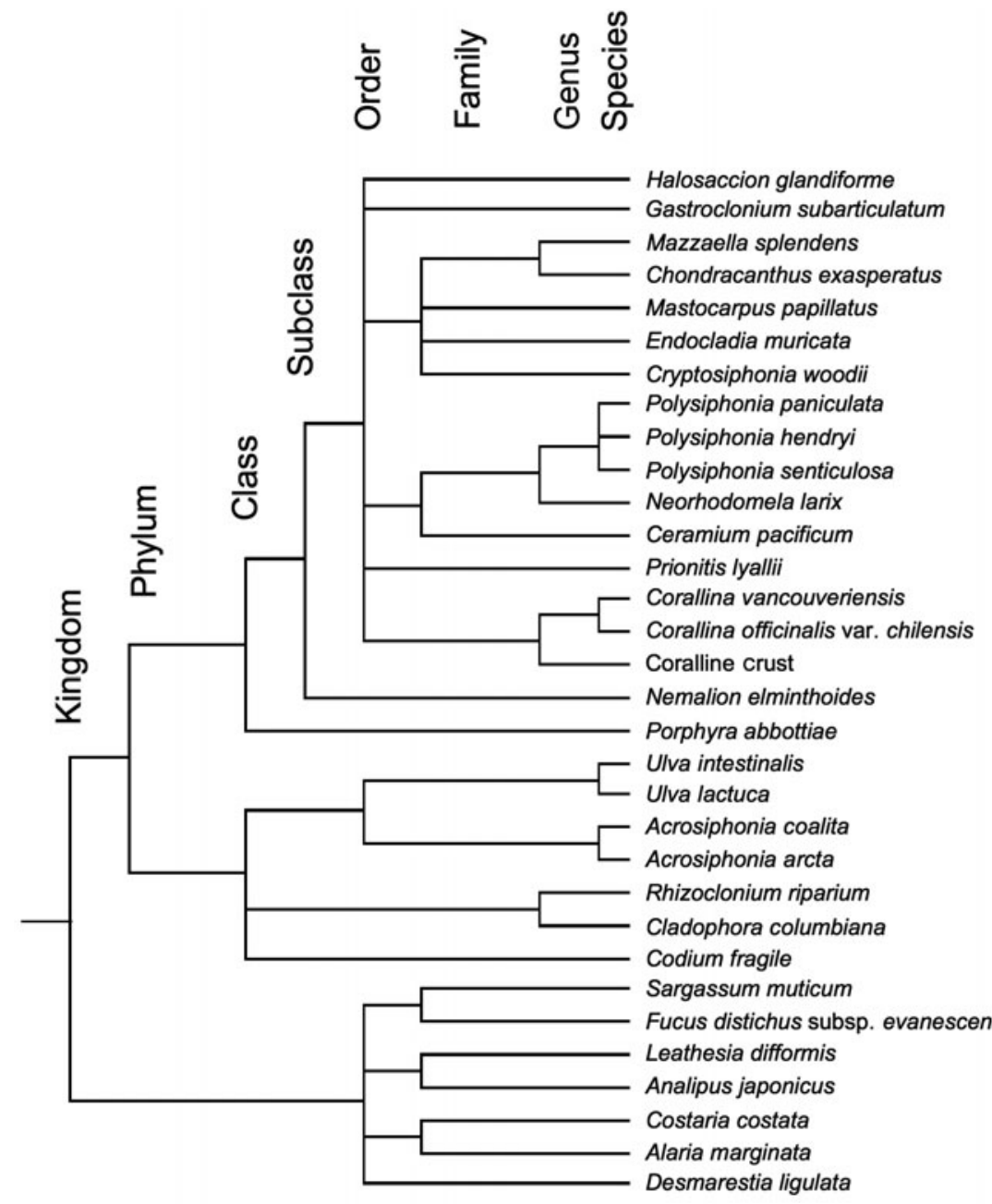

Fig. 2. Dendrogram illustrating taxonomic relationships between algal species investigated as hosts for small mobile invertebrate epifauna. Taxonomic relationships follow Gabrielson et al. (2006)

isopods $(4.0 \%)$, mites $(3.6 \%)$, polychaete worms $(2.8 \%)$, and nematodes $(2.2 \%)$. I focus here on community-level invertebrate responses; population responses of invertebrate taxa will be reported in a separate study.

\section{Algal taxonomic distance}

Similarity of invertebrate assemblages did not decrease as taxonomic distances between seaweed hosts increased; invertebrate assemblages were as similar between congeneric algal hosts as between algal species in different kingdoms (Wilcoxon, $\chi=6.93$, df $=7, \mathrm{p}=$ 0.44; Fig. 3).

\section{Across functional groups}

Invertebrate assemblages were different across most algal functional groups (ANOSIM, $R=0.209$, p < 0.001; Table 2). However, geniculate coralline algae had similar invertebrate composition to leathery, corticated terete, corticated foliose, and foliose functional groups. Crustose and corticated foliose functional groups harbored similarly sparse assemblages.

Invertebrate taxon richness was different across some, but not all, algal functional groups ( $\mathrm{p}<0.002$; Fig. 4, upper panel). The filamentous, foliose, corticated foliose, and corticated terete

created through 4999 randomizations (with replacement) of the values for both groups.

Multivariate results and taxonomic distances were obtained using PRIMER software (version 6.1.6, Primer-E, www.primer-e.org). Parametric univariate analyses were performed using JMPin (Version 4.0.4, SAS Institute) and randomization procedures were achieved using PopTools (Hood 2006).

\section{RESULTS}

A total of 54776 individuals were sampled across 98 taxa of mobile invertebrate epifauna. The majority of these individuals came from a small number of higher taxa, including gammarid amphipods (47.9\%), harpacticoid and cyclopoid copepods $(18.4 \%)$, juvenile bivalve mollusks $(12.2 \%)$, gastropod mollusks $(5.0 \%)$, functional groups were not significantly different $(\mathrm{p}>$ 0.05). The crustose group was significantly different because it had few, if any, taxa associated with it, and

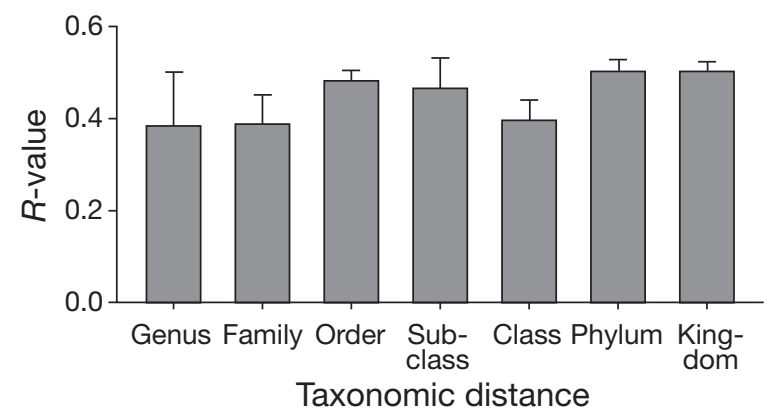

Fig. 3. ANOSIM $R$-values indicating similarity of invertebrate assemblages between algal species within 7 groups of increasing taxonomic distance. No differences were observed between groups $(p=0.44)$. Bars report mean values $(+\mathrm{SE})$ 
the leathery and geniculate coralline functional groups were not significantly different from either the former or the latter set of functional groups.

No differences across algal functional groups were noted for abundance of invertebrates (Fig. 4, lower panel), although the results were marginally nonsignificant $(p=0.081)$.

\section{Within functional groups}

There was little evidence to support the prediction that algal species within the same functional group were functionally equivalent. Composition of invertebrate assemblages (Appendix 1) was different for most pairwise comparisons within most of the functional groups. Only 5 of 28 possible pairwise comparisons were nonsignificant in the filamentous functional group (Appendix 1). The corticated foliose group showed 1 nonsignificant result out of 10, corticated terete showed 1 out of 36, and leathery showed 1 out of 6 . Within the foliose and geniculate coralline groups, all of the species had different invertebrate assemblages, whereas in the crustose group, the 2 species had the same type of assemblage. Similarity of invertebrate assemblages across samples within each algal species was variable across algal species (Table 1) but relatively consistent across algal functional groups. Foliose, coralline, corticated terete, and corticated foliose algae had very similar levels of variation within groups $(33.13,34.90,34.18$, and $34.66 \%$, respectively), whereas filamentous algae had more consistent invertebrate assemblages across samples (43.98\%) and leathery algae had more variable invertebrate assemblages $(23.72 \%)$.

For rarefied invertebrate taxon richness and invertebrate abundance (Fig. 4), most algal species had a mean richness and abundance that differed from the functional group mean $(p<0.05)$. Notable exceptions include the filamentous group, for which rarefied invertebrate richness was consistent with the functional group mean for most taxa, although Polysiphonia senticulosa and Rhizoclonium riparium were, respectively, well below and above the filamentous group mean. However, despite this relative consistency in taxon richness, invertebrate abundance was variable across the filamentous group. Rarefied richness and composition were the same for species within the coralline and crustose groups; however only 2 species were represented in each functional group.

\section{DISCUSSION}

\section{Taxonomic relatedness of seaweed host}

Knowledge of the influence of host relatedness on associated fauna is potentially important to the estimation of global species diversity (Ødegaard et al. 2005), for predicting the ecological performance of host species, and understanding community assembly. However, although several recent studies examine the influence of genetic diversity on associated marine invertebrates within single host species (Hughes \& Stachowicz 2004, Johnson et al. 2006), cross-species tests of linkages between host plant relatedness and associated fauna are limited (Farrell \& Mitter 1990, Losos 1996, Kelly \& Southwood 1999, Ødegaard et al. 2005, Weiblen et al. 2006). The results of the present study show that seaweed host taxonomic relatedness does not inform predictions about differences in diversity of associated small mobile invertebrates. I found that mobile invertebrate assemblages were as different on sibling algal species as on hosts classified in different kingdoms (Fig. 2).

Table 2. $R$-values (top) and p-values (bottom) from the ANOSIM test for differences in invertebrate epifauna assemblages across 7 algal functional groups. Bold text indicates no significant difference between groups $(p>0.05)$

\begin{tabular}{|c|c|c|c|c|c|c|}
\hline & Leathery & $\begin{array}{c}\text { Corticated } \\
\text { terete }\end{array}$ & $\begin{array}{l}\text { Corticated } \\
\text { foliose }\end{array}$ & Filamentous & Crustose & Coralline \\
\hline Foliose & $\begin{array}{r}0.122 \\
<0.001\end{array}$ & $\begin{array}{r}0.113 \\
<0.001\end{array}$ & $\begin{array}{r}0.147 \\
<0.001\end{array}$ & $\begin{array}{r}0.358 \\
<0.001\end{array}$ & $\begin{array}{r}0.542 \\
<0.001\end{array}$ & $\begin{array}{r}0.090 \\
<0.048\end{array}$ \\
\hline Leathery & & $\begin{array}{r}0.208 \\
<0.001\end{array}$ & $\begin{array}{r}0.172 \\
<0.001\end{array}$ & $\begin{array}{r}0.419 \\
<0.001\end{array}$ & $\begin{array}{r}0.200 \\
<0.001\end{array}$ & $\begin{array}{l}0.067 \\
\mathbf{0 . 0 9 8}\end{array}$ \\
\hline Corticated terete & & & $\begin{array}{r}0.233 \\
<0.001\end{array}$ & $\begin{array}{r}0.151 \\
<0.001\end{array}$ & $\begin{array}{r}0.593 \\
<0.001\end{array}$ & $\begin{array}{l}0.041 \\
\mathbf{0 . 1 9 4}\end{array}$ \\
\hline Corticated foliose & & & & $\begin{array}{r}0.373 \\
<0.001\end{array}$ & $\begin{array}{l}0.044 \\
\mathbf{0 . 0 8 8}\end{array}$ & $\begin{array}{l}0.036 \\
\mathbf{0 . 2 0 3}\end{array}$ \\
\hline Filamentous & & & & & $\begin{array}{r}0.859 \\
<0.001\end{array}$ & $\begin{array}{r}0.320 \\
<0.001\end{array}$ \\
\hline Crustose & & & & & & $\begin{array}{r}0.884 \\
<0.001\end{array}$ \\
\hline
\end{tabular}




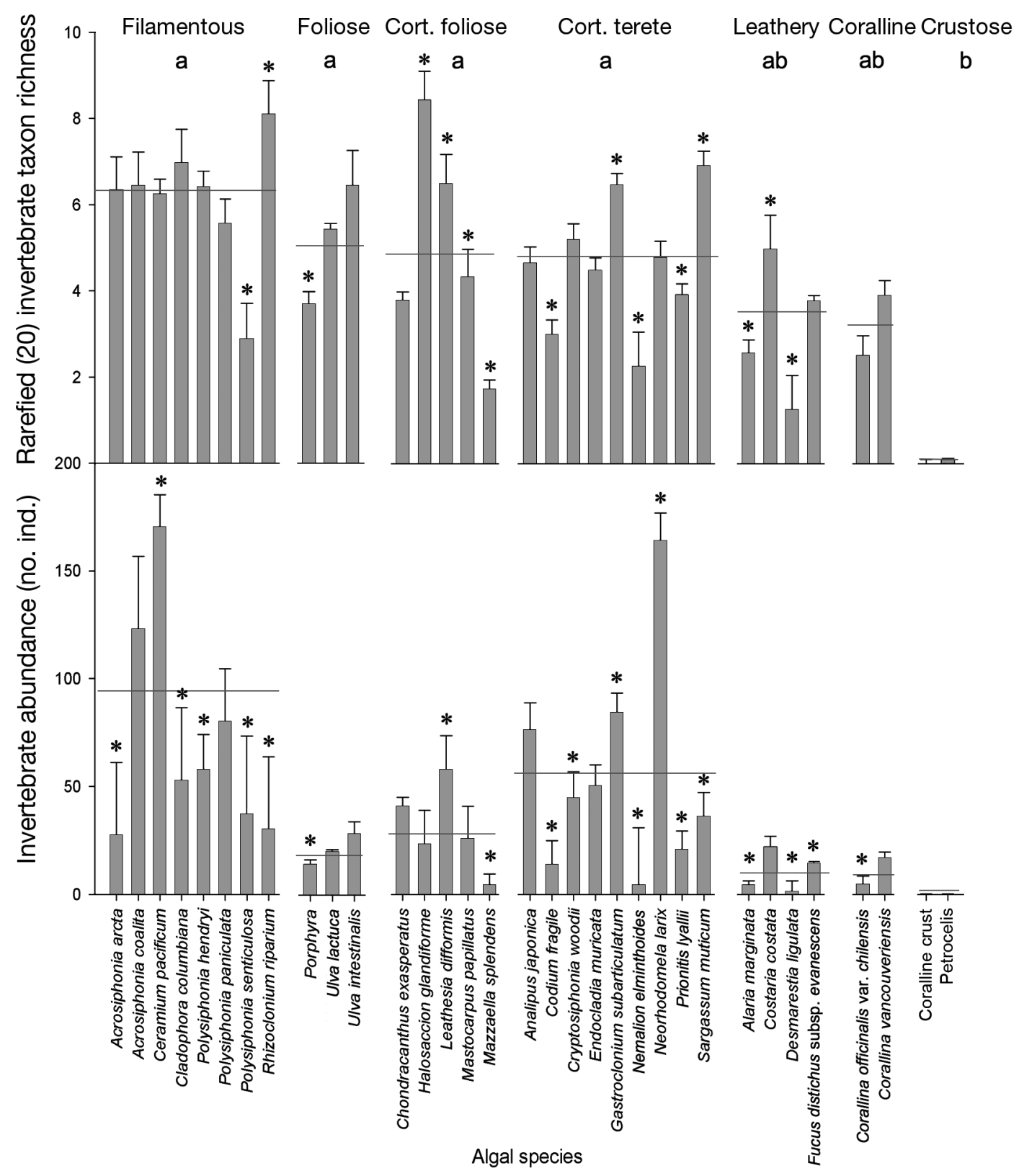

Fig. 4. Comparisons of rarefied (20 individuals) invertebrate taxon richness (upper panel) and invertebrate abundance (lower panel) for algal species within 7 algal functional groups. Horizontal bars indicate the mean value for each functional group. Shared letters (upper panel) indicate no significant difference between algal functional groups ( $p>0.05)$. Invertebrate abundance (lower panel) did not differ across algal functional groups $(p=0.08){ }^{*}$ : species mean differs from the functional group mean $(\mathrm{p}<0.05)$. Bars report mean values $(+\mathrm{SE})$

Where host relatedness of terrestrial plants has been investigated as a predictor of diversity of associated phytophagous insects, some predictive value has been demonstrated. Insect assemblages are more similar on plant hosts from the same genus and family, but not at higher taxonomic distances (Ødegaard et al. 2005, Weiblen et al. 2006), and specificity of insect to host is invoked as an explanation for this relationship. Congruence in patterns of diversification between host and herbivore clades indicates that specialization could be a result of coevolution between host plants and specialist feeders (Farrell \& Mitter 1990). The relationship between host phylogeny and phytophagous insects makes sense because herbivorous insects prefer closely related plants that are similar in chemistry and resource provision. This is not the case in the marine system examined in the present study; many seaweed epifauna do not consume their host (Arrontes 1999), 
and therefore tend to be more general in their host use patterns. As suggested above, marine invertebrate epifauna select seaweed hosts based on internal and external features, yet seaweed form has been shown to be a stronger regulator of invertebrate epifauna than palatability or defensive chemistry (Dean \& Connell 1987, Norderhaug 2004). It is therefore not surprising that seaweed taxonomic relatedness was not congruent with observed patterns of associated invertebrates. Additional support for the lack of influence of host taxonomic relatedness on associated invertebrates is provided by the observation of a single species exhibiting an alternation of heteromorphic generations (Mastocarpus papillatus), which shows that, even within the same species, functionally different forms may support different invertebrate assemblages (Fig. 4, Mastocarpus papillatus vs. Petrocelis).

It is important to note that seaweed taxonomy is currently in flux, and even major groups like the Rhodophyta are subject to substantial higher-level taxonomic rearrangement (Saunders \& Hommersand 2004). Furthermore, genetic distances between seaweed taxa classified to the same taxonomic ranks are not always equal. However, given the often-demonstrated linkages between algal host morphology and invertebrate diversity (Martin-Smith 1993, Davenport et al. 1996, Attrill et al. 2000, Davenport et al. 1999, McAbendroth et al. 2005), it is unlikely that my conclusions would change given a revised algal taxonomy.

\section{Seaweed functional groups}

Differences were observed across several algal functional (i.e. morphological) groups for invertebrate composition, yet fewer between-group differences were noted for number of invertebrate taxa and no differences were seen for invertebrate abundance (Table 2, Fig. 4). Morphologically based algal functional groups have had variable success for predicting seaweedinvertebrate interactions (Hawkins \& Hartnoll 1983, Arrontes 1990, Duffy \& Hay 1991, Wakefield \& Murray 1998), and Padilla \& Allen's (2000) suggestion that algal functional form groups could be applied to habitat provision was not well supported here. Observations of invertebrate richness across functional groups tend, on average, to follow common perceptions about relationships between algal thallus complexity and invertebrate diversity. Specifically, the complexly branching filamentous and corticated terete functional groups tended to have the most associated invertebrates, whereas simple groups (i.e. flat blades from the corticated foliose and leathery groups, and crustose groups) tended to have the fewest (Fig. 4, horizontal bars). However, there was substantial variation within functional groups (Fig. 4, vertical bars), suggesting that functional group performance actually indicates little about the performance of the constituent species.

Hay (1994) suggested that if, in general, ecologically meaningful seaweed functional groups could be erected, these patterns of similarity could then lead naturally to discussions of species differences. However, based on my observations across a large number of seaweed species, it appears that invertebrate selection of seaweed host is largely dependent upon the identity of the host species, not the functional group. While there is no question that algal morphology influences the diversity of associated invertebrates, it appears that the relationship between host morphology and invertebrate assemblages is not straightforward (i.e. increased architectural complexity does not directly lead to higher diversity of associated invertebrates), a phenomenon that is not uncommon when considering questions of functional morphology (Koehl 1996). Several possible explanations exist to explain the variable performance of host species within algal functional groups.

First, once invertebrates choose a host based on gross morphology, host selection decisions may be refined based on internal features of seaweeds. While I have not directly tested any internal variables here, I do show that complexly branching algae with very similar external features can host different invertebrate assemblages. For example, species within filamentous and corticated terete groups (Fig. 4), and even congeneric algae with very similar forms (e.g. Acrosiphonia coalita vs. Acrosiphonia arcta) have a very different number of associated invertebrates. This latter result is similar to observations that the invasive species Fucus evanescens C. Ag. is utilized less by epifauna than the native congener $F$. vesiculosus L. along European coasts (Wikström \& Kautsky 2004). These types of observations draw into question the use of seaweed architectural complexity as a predictor of associated invertebrates; this often-cited regulator of seaweed-epifauna associations does not appear to be a wholly reliable criterion for generalization.

Second, seaweed functional groups are traditionally delineated based on morphological features of individual thalli (Steneck \& Dethier 1994). However, morphology complexity is a parameter that can vary across scales of observation (Kingsford 1995, McAbendroth et al. 2005). For example, at a small (i.e. algal thallus) scale, architectural complexity may be considered as branching complexity (Chemello \& Milazzo 2002), whereas at broader (i.e. seaweed stand) scales, arrangement of the individual thalli in space influences invertebrate habitat choices (Goodsell \& Connell 2002, 2005, Goodsell et al. 2004, Roberts \& Poore 2006). 
These 2 scales of architectural complexity can differentially affect various types or sizes of seaweedassociated invertebrates (Hacker \& Steneck 1990) or modify the effects of different abiotic and biotic stressors.

It is possible that the functional groups erected by Steneck \& Dethier (1994) are not defined according to parameters that are relevant to habitat use by small mobile invertebrate epifauna. Padilla \& Allen (2000) suggested that algal functional groups should be based not on gross morphology but on particular functions, and then tested before being generally applied across taxa. However, in examining the suite of species tested here, it seems unlikely that meaningful functional groups could be defined; while there is an apparent gradient of habitat use by invertebrates, no groups of similarly functioning algal species were observed (Fig. 4). As such, replacements by equivalent or redundant taxa appear unlikely.

\section{Is there hope for generalizations about seaweed-epifauna associations?}

The 2 frameworks tested here (taxonomic relatedness and algal functional group affiliation) do not appear useful for informing predictions of habitat use by invertebrate epifauna. However, several options still exist as possibilities for generalizing about seaweed-epifauna associations; I offer here several suggestions for future research.

First, the marine system studied here embodies a much wider taxonomic breadth in both host plants and associated invertebrates compared to terrestrial insecthost plant systems. Invertebrate functional groups, based on feeding and bioturbation types, have been successful elsewhere (Mermillod-Blondin et al. 2002, Rabeni et al. 2005) and may offer some resolution in this marine system. For example, marine invertebrate mesoherbivores may show a stronger affinity for specific algal hosts than was revealed by the broad, community-wide assessment of invertebrate epifauna described here.

Second, given the observed gradient of host use across algal taxa, it would be interesting to look for particular algal traits that could be measured on a continuous scale, instead of discrete groups that integrate suites of algal traits. Chemello \& Milazzo (2002) examined variation in 9 morphological traits across 6 brown algal species, and showed that degree of branching alone explained over $60 \%$ of the variation in plantmollusc assemblages. This approach holds promise, although difficulties can arise when looking for morphological traits that are shared across a broad spectrum of algal morphologies.
Lastly, the small proportion of variance explained by the seaweed traits tested here suggests that factors other than seaweed traits are influencing habitat choices by small mobile invertebrates. It is highly likely that abiotic environmental conditions are also integrated into habitat choices by epifauna.

Acknowledgements. I thank R. DeWreede, D. Srivastava, R. Turkington, S. Lindstrom, and 2 anonymous reviewers for comments on earlier drafts of this manuscript; L. Hassal and R. Dickson for help in the lab and field; the staff of the Bamfield Marine Sciences Centre for logistic support; and the Huu-Ahy-Aht First Nation for access to their traditional territory. Support for C.R.B. during this study was provided by the National Sciences and Engineering Research Council of Canada and fellowships from the University of British Columbia and the Bamfield Marine Sciences Centre.

\section{LITERATURE CITED}

Arrontes J (1990) Diet, food preference, and digestive efficiency in intertidal isopods inhabiting macroalgae. J Exp Mar Biol Ecol 139:231-249

> Arrontes J (1999) On the evolution of interactions between marine mesoherbivores and algae. Bot Mar 42:137-155

> Attrill MJ, Strong JA, Rowden AA (2000) Are macroinvertebrate communities influenced by seagrass structural complexity? Ecography 23:114-121

Bray JR, Curtis JT (1957) An ordination of the upland forest communities of southern Wisconsin. Ecol Monogr 27: 325-349

Chemello R, Milazzo M (2002) Effect of algal architecture on associated fauna: some evidence from phytal molluscs. Mar Biol 140:981-990

> Christie H, Jorgensen NM, Norderhaug KM, Waage-Nielsen E (2003) Species distribution and habitat exploration of fauna associated with the kelp (Laminaria hyperborea) along the Norwegian coast. J Mar Biol Assoc UK 83: 687-699

Clarke KR (1993) Non-parametric multivariate analysis of changes in community structure. Aust J Ecol 18:117-143

Colman J (1939) On the faunas inhabiting intertidal seaweeds. J Mar Biol Assoc UK 24:129-183

> Davenport J, Pugh PJA, McKechnie J (1996) Mixed fractals and anisotropy in subantarctic marine macroalgae from South Georgia: implications for epifaunal biomass and abundance. Mar Ecol Prog Ser 136:245-255

Davenport J, Butler A, Cheshire A (1999) Epifaunal composition and fractal dimensions of marine plants in relation to emersion. J Mar Biol Assoc UK 79:351-355

> Dean RL, Connell JH (1987) Marine invertebrates in algal succession. II. Tests of hypotheses to explain diversity with succession. J Exp Mar Biol Ecol 109:217-247

> Diaz S, Cabido M (2001) Vive la difference: plant functional diversity matters to ecosystem processes. Trends Ecol Evol 16:646-655

Duffy JE, Hay ME (1991) Food and shelter as determinants of food choice by an herbivorous marine amphipod. Ecology 72:1286-1298

> Farrell BD, Mitter C (1990) Phylogenesis of insect/plant interactions: Have Phyllobrotica leaf beetles (Chrysomelidae) and the Lamiales diversified in parallel? Evolution 44: 1389-1403

Fonseca CR, Ganade G (2001) Species functional redun- 
dancy, random extinctions, and stability of ecosystems. J Ecol 89:118-125

Gabrielson PW, Widdowson TB, Lindstrom SC (2006) Keys to the seaweeds and seagrasses of southeast Alaska, British Columbia, Washington, and Oregon. Phycological Contribution No. 7. University of British Columbia, Vancouver, BC

Gee JM, Warwick RM (1994) Metazoan community structure in relation to the fractal dimension of marine macroalgae. Mar Ecol Prog Ser 103:141-150

- Goodsell PJ, Connell SD (2002) Can habitat loss be treated independently of habitat configuration? Implications for rare and common taxa in fragmented landscapes. Mar Ecol Prog Ser 239:37-44

Goodsell PJ, Connell SD (2005) Historical configuration of habitat influences the effects of disturbance on mobile invertebrates. Mar Ecol Prog Ser 299:79-87

Goodsell PJ, Fowler-Walker MJ, Gillanders BM, Connell SD (2004) Variations in the configuration of algae in subtidal forests: Implications for invertebrate assemblages. Austral Ecol 29:350-357

Graham LE, Wilcox LW (2000) Algae. Prentice Hall, Upper Saddle River, NJ

Hacker SD, Steneck RS (1990) Habitat architecture and the abundance and body-size-dependent habitat selection of a phytal amphipod. Ecology 71:2269-2285

Hawkins SJ, Hartnoll RG (1983) Grazing of intertidal algae by marine invertebrates. Oceanogr Mar Biol 21:195-282

Hay ME (1994) Species as 'noise' in community ecology: Do seaweeds block our view of the kelp forest? Trends Ecol Evol 9:414-416

> Hay ME, Duffy JE, Pfister CA, Fenical W (1987) Chemical defense against different marine herbivores: Are amphipods insect equivalents? Ecology 68:1567-1580

Hay ME, Duffy JE, Paul VJ, Renaud PE, Fenical W (1990) Specialist herbivores reduce their susceptibility to predation by feeding on the chemically defended seaweed Avrainvillea longicaulis. Limnol Oceanogr 35:1734-1743

Hayward PJ (1980) Invertebrate epiphytes of coastal marine algae. In: Price JH, Irvine DEG, Farnham WF (eds) The shore environment: 2. Ecosystems. Academic Press, London, p 761-787

Hayward PJ (1988) Animals on seaweed, Vol 9. Richmond Publishing, Richmond, VA

> Holmlund MB, Peterson CH, Hay ME (1990) Does algal morphology affect amphipod susceptibility to fish predation? J Exp Mar Biol Ecol 139:65-83

Hood GM (2006) PopTools version 2.7.5. Available at www.cse.csiro.au/poptools

Hughes AR, Stachowicz JJ (2004) Genetic diversity enhances the resistance of a seagrass ecosystem to disturbance. Proc Natl Acad Sci USA 101:8998-9002

Hull SL (1997) Seasonal changes in diversity and abundance of ostracods on four species of intertidal algae with differing structural complexity. Mar Ecol Prog Ser 161:71-82

Ji Y, Tanaka J (2002) Effect of desiccation on the photosynthesis of seaweeds from the intertidal zone in Honshu, Japan. Phycol Res 50:145-153

Johnson MTJ, Lajeunesse MJ, Agrawal AA (2006) Additive and interactive effects of plant genotypic diversity on arthropod communities and plant fitness. Ecol Lett 9: 24-34

Kelly CK, Southwood TRE (1999) Species richness and resource availability: a phylogenetic analysis of insects associated with trees. Proc Natl Acad Sci USA 96: 8013-8016

Kingsford MJ (1995) Drift algae: a contribution to near-shore habitat complexity in the pelagic environment and an attractant for fish. Mar Ecol Prog Ser 116:297-301

Koehl MAR (1996) When does morphology matter? Annu Rev Ecol Syst 27:501-542

- Kraufvelin P, Salovius S (2004) Animal diversity in Baltic rocky shore macroalgae: Can Cladophora glomerata compensate for lost Fucus vesiculosus? Estuar Coast Shelf Sci 61:369-378

Lavorel S, McIntyre S, Landsberg J, Forbes TDA (1997) Plant functional classifications: from general groups to specific groups based on response to disturbance. Trends Ecol Evol 12:474-478

Littler MM, Littler DS (1980) The evolution of thallus form and survival strategies in benthic marine macroalgae: field and laboratory tests of a functional form model. Am Nat 116:25-44

Loreau M (2004) Does functional redundancy exist? Oikos 104:606-611

Losos JB (1996) Phylogenetic perspectives on community ecology. Ecology 77:1344-1354

MacArthur RH (1972) Geographical ecology: patterns in the distribution of species. Princeton University Press, Princeton, NJ

Magurran AE (1988) Ecological diversity and its measurement. Princeton University Press, Princeton, NJ

Manly BFJ (1991) Randomization and Monte Carlo methods in biology. Chapman \& Hall, London

Martin-Smith KM (1993) Abundance of mobile epifauna: the role of habitat complexity and predation by fishes. J Exp Mar Biol Ecol 174:243-260

> McAbendroth L, Ramsay PM, Foggo A, Rundle D, Bilton DT (2005) Does macrophyte fractal complexity drive invertebrate diversity, biomass and body size distributions. Oikos 111:279-290

Mermillod-Blondin F, Gérino M, Creuzé des Châtelliers M, Degrange V (2002) Functional diversity among 3 detritivorous hyporheic invertebrates: an experimental study in microcosms. J N Am Benthol Soc 21:132-149

> Naeem S (1998) Species redundancy and ecosystem reliability. Conserv Biol 12:39-45

> Norderhaug KM (2004) Use of red algae as hosts by kelpassociated amphipods. Mar Biol 144:225-230

Norderhaug KM, Christie H, Fossa JH, Fredriksen S (2005) Fish-macrofauna interactions in a kelp (Laminaria hyperborea) forest. J Mar Biol Assoc UK 85:1279-1286

Ødegaard F, Diserud OH, Østbye K (2005) The importance of plant relatedness for host utilization among phytophagous insects. Ecol Lett 8:612-617

Padilla DK, Allen BG (2000) Paradigm lost: reconsidering functional form and group hypotheses in marine ecology. J Exp Mar Biol Ecol 250:207-221

> Paine RT, Vadas RL (1969) Calorific values of benthic marine algae and their postulated relation to invertebrate food preference. Mar Biol 4:79-86

Rabeni CF, Doisy KE, Zweig LD (2005) Stream invertebrate community functional responses to deposited sediment. Aquat Sci 67:395-402

Roberts DA, Poore AGB (2006) Habitat configuration affects colonisation of epifauna in a marine algal bed. Biol Conserv 127:18-26

> Rosenfeld JS (2002) Functional redundancy in ecology and conservation. Oikos 98:156-162

Saunders GW, Hommersand MH (2004) Assessing red algal supraordinal diversity and taxonomy in the context of contemporary systematic data. Am J Bot 91:1494-1507

> Seed R, O'Connor RJ (1981) Community organization in marine algal epifaunas. Annu Rev Ecol Syst 12:49-74 
Silva PC (1992) Geographic patterns of diversity in benthic marine algae. Pac Sci 46:429-437

Steneck RS, Dethier MN (1994) A functional group approach to the structure of algal-dominated communities. Oikos 69:476-498

Steneck RS, Watling L (1982) Feeding capabilities and limitation of herbivorous molluscs: a functional group approach. Mar Biol 68:299-319

Taylor RB, Cole RG (1994) Mobile epifauna on subtidal brown seaweeds in northeastern New Zealand. Mar Ecol Prog Ser 115:271-282

Taylor RB, Steinberg PD (2005) Host use by Australasian seaweed mesograzers in relation to feeding preferences of larger grazers. Ecology 86:2955-2967

Thebault E, Loreau M (2006) The relationship between biodiversity and ecosystem functioning in food webs. Ecol
Res 21:17-25

Van Alstyne KL, Houser LT (2003) Dimethylsulfide release during macroinvertebrate grazing and its role as an activated chemical defense. Mar Ecol Prog Ser 250:175-181

Wakefield RL, Murray SN (1998) Factors influencing food choice by the seaweed-eating marine snail Norrisia norrisi (Trochidae). Mar Biol 130:631-642

Webb CO, Ackerly DD, McPeek MA, Donoghue MJ (2002) Phylogenies and community ecology. Annu Rev Ecol Syst 33:475-505

Weiblen GD, Webb CO, Novotny V, Basset Y, Miller SE (2006) Phylogenetic dispersion of host use in a tropical insect herbivore community. Ecology 87(Suppl):62-75

Wikström SA, Kautsky L (2004) Invasion of a habitat-forming seaweed: effects on associated biota. Biol Invasions 6: $141-150$

Appendix 1. $R$-values (top) and p-values (bottom) from ANOSIM tests for comparing invertebrate epifauna assemblages across algal species within 6 functional groups. Bold text indicates no significant difference between species $(p>0.05)$

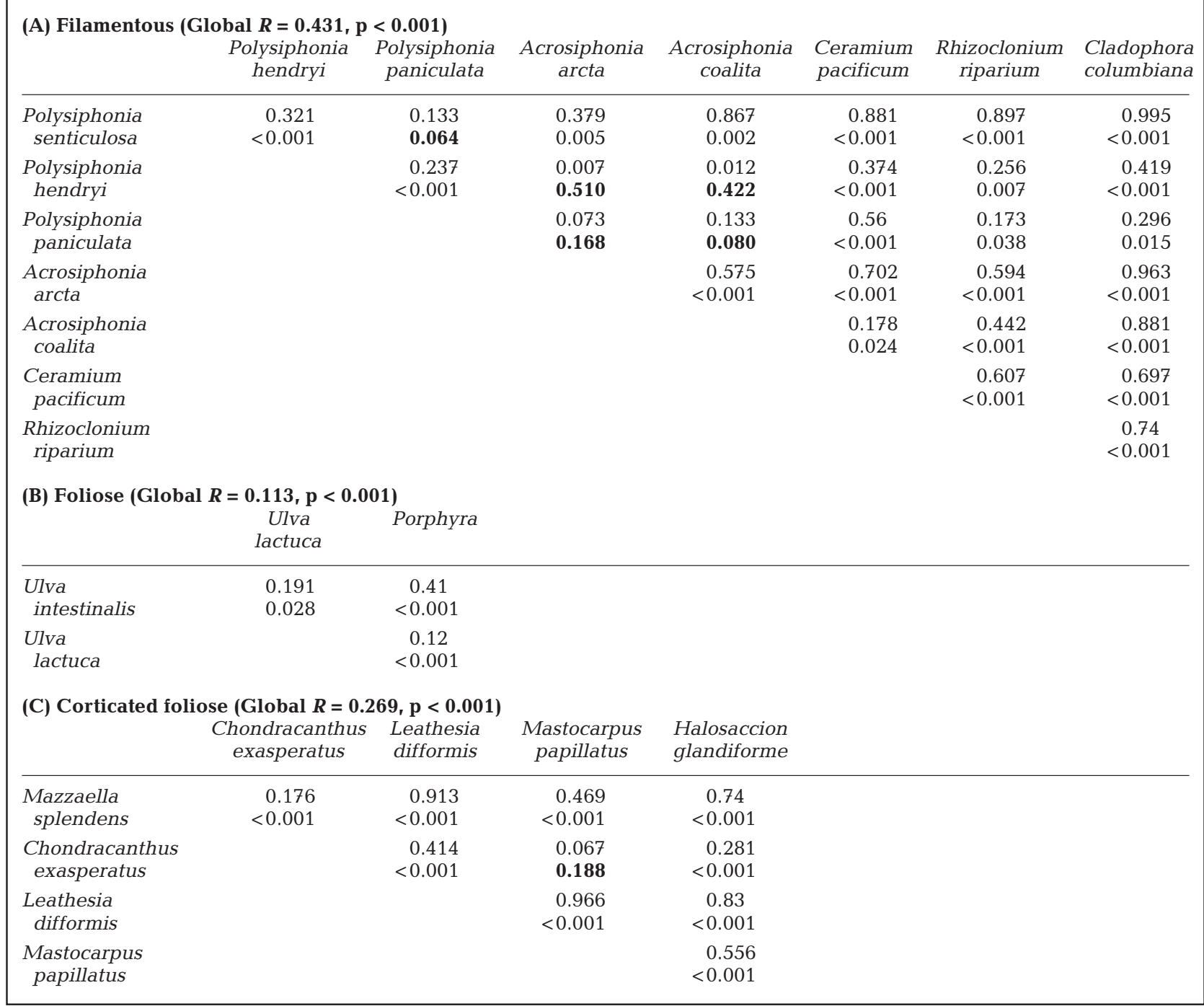


Appendix 1 (continued)

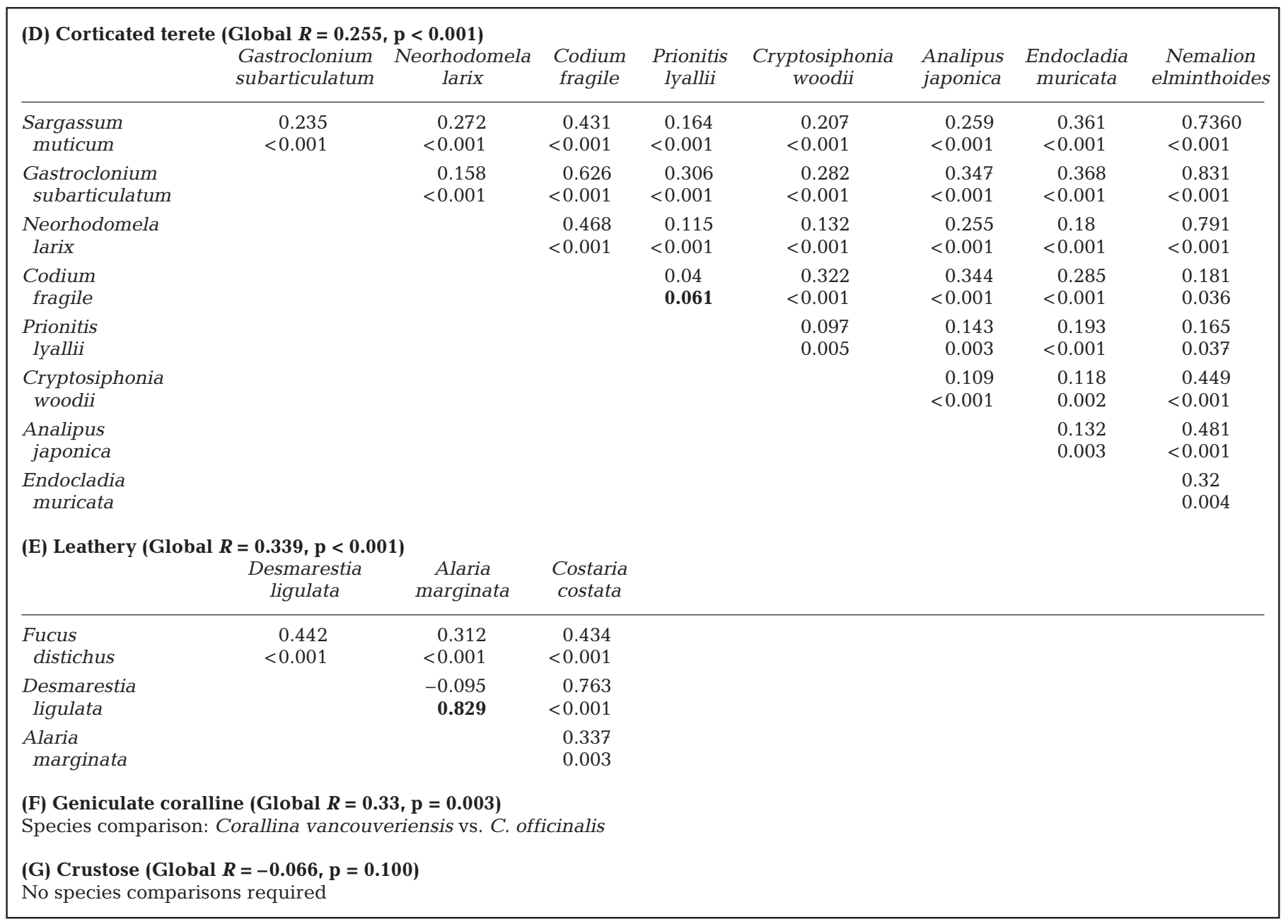

Editorial responsibility: Richard Osman, Edgewater, Maryland, USA
Submitted: November 17, 2008; Accepted: April 24, 2009 Proofs received from author(s): July 9, 2009 